\title{
PROGRAM PENGAJARAN KOKURIKULER DALAM MENINGKATKAN KEMAMPUAN EMOTIONAL QUOTIENT (EQ) SISWA DI MTS TAHFIDZ YANBU'UL QUR'AN KUDUS
}

\author{
Yogik Delta Hermawan \\ IAIN Kudus
}

\begin{abstract}
Emotional Quotient is an ability that should be owned by each student. Because emotional quotient includes a process that tames emotions and directs them to positive things, for that we need a program in the world of education that is able to respond to this. This study describes how the implementation of the co-curricular preparation program in improving the emotional quotient abilities of MTs Tahfidz Yanbu'ul Qur'an Kudus students. This research uses descriptive qualitative method. The data sources were headmaster, deputy head of curriculum, teachers, and students. Meanwhile, secondary data are relevant research books and journals. Collecting data using observation, interviews, and documentation. The results showed that the implementation of a co-curricular program could improve students' EQ skills. This is evident from the fact that students who often participate in this program have a high sense of respect, responsibility, empathy, and high motivation. Meanwhile, students who rarely participate in co-curricular programs tend to be indifferent and have low motivation. Supporting factors for the implementation of the co-curricular program are the competence of quality teachers, facilities and infrastructure, and monitoring from the principal of madrasah. Meanwhile, the inhibiting factors are the lack of teaching staff, implementation time and non-technical factors.
\end{abstract}

Keywords: Teaching; Co-curricular; Emotional Quotient

Abstrak : Emotional Quotient merupakan sebuah kemampuan yang sudah seharusnya dimiliki oleh masing-masing siswa. Karena emotional quotient di dalamnya terdapat proses menjinakkan emosi dan mengarahkannya kepada hal-hal yang positif, untuk itu diperlukan sebuah program dalam dunia pendidikan yang mampu merespon hal tersebut. Penelitian ini menggambarkan bagaimana pelaksanaan program pengajaran kokurikuler dalam meningkatkan kemampuan emotional quotient siswa MTs Tahfidz Yanbu'ul Qur'an Kudus. Penelitian ini menggunakan metode kualitatif deskriptif. Sumber data primer yaitu kepala madrasah, wakil kepala bidang kurikulum, guru, dan siswa. Sedangkan data sekunder yaitu buku dan jurnal penelitian yang relevan. Pengumpulan data menggunakan observasi, wawancara, dan dokumentasi. Hasil penelitian menunjukkan bahwa pelaksanaan program pengajaran kokurikuler dapat meningkatkan kemampuan EQ siswa. Ini 
terbukti dengan siswa yang sering mengikuti program ini memiliki rasa menghargai yang tinggi, bertanggung jawab, empati, dan memiliki motivasi tinggi. Sedangkan siswa yang jarang mengikuti program kokurikuler cenderung acuh tak acuh dan motivasi rendah. Faktor pendukung pelaksanaan program kokurikuler yaitu kompetensi guru yang berkualitas, sarana dan prasarana, dan monitoring dari kepala madrasah. Sedangkan faktor yang menghambat yaitu masih kurangnya tenaga pendidik, waktu pelaksanaan, dan faktor non teknis.

Kata Kunci : Pengajaran; Kokurikuler; Emotional Quotient

\section{A. PENDAHULUAN}

Pendidikan merupakan sebuah istilah yang sudah melekat dikalangan masyarakat umum. Dalam bahasa Inggris, pendidikan berasal dari kata education yang diturunkan dari kata educate dengan arti memberi sebuah peningkatan (to elicit, and to give rise to). Selain itu juga bermakna mengembangkan (Haryu, 2014: 3-4). Pengertian pendidikan secara luas adalah pendidikan diartikan sebagai "hidup". Makna dari kata hidup adalah pendidikan merupakan segala pengalaman belajar yang berlangsung disepanjang lingkungan dan sepanjang hidup. Pendidikan adalah situasi yang dapat digunakan untuk mempengaruhi pertumbuhan individu menuju ke arah yang lebih positif (Redja, 2013: 3).

Dalam dunia pendidikan, terdapat dua hal yang tidak dapat dipisahkan yaitu pengajaran dan pembelajaran. Pada dasarnya pembelajaran merupakan suatu proses yang terdiri dari kombinasi dua aspek, yaitu belajar yang tertuju kepada apa yang harus dilakukan oleh siswa. Serta mengajar berorientasi pada apa yang harus dilakukan oleh guru sebagai pemberi materi pelajaran. Kedua aspek ini harus berkolaborasi secara terpadu menjadi sebuah kegiatan, baik di dalam maupun di luar kelas. Selain itu harus mengedepankan iklim edukatif guna mencapai tujuan pendidikan yang diharapkan (Asep, 2013: 11-12). Terkait istilah pengajaran, dalam bahasa Arab disebut "taklim" yang berasal dari kata "allama" dan memliki padanan kata "hazzaba". Secara umum, pengajaran merupakan sebuah program kependidikan yang sudah direncanakan dan diarahkan agar bisa mencapai tujuan yang diharapkan, serta dirancang untuk mempermudah kegiatan belajar mengajar. Sehingga sebuah pendidikan dapat berjalan dengan sukses, efektif dan efisien (Muhibbin: 2016, 33). 
Terdapat begitu banyak tipe pengajaran dalam dunia pendidikan. Namun penelitian ini hanya akan fokus terkait program pengajaran kokurikuler diluar jam pelajaran. Program pengajaran kokurikuler merupakan sebuah kegiatan yang dimaksudkan untuk lebih mendalami materi pelajaran yang telah dipelajari di dalam kelas, baik yang tergolong mata pelajaran inti maupun umum. Berkaitan dengan dinamika di atas, peneliti menemukan sebuah realita menarik di MTs Tahfidz Yanbu'ul Qur'an Kudus. Program pengajaran kokurikuler di madrasah ini berupa kegiatan belajar malam, dengan sistem hampir sama dengan sistem kelas formal pada pagi hari. Tujuan dari program ini adalah agar siswa memiliki penguasaan materi yang lebih mendalam dan komprehensif. Serta memiliki 3 (tiga) kecerdasan dasar yaitu kognitif, afektif, dan psikomotorik. Dengan adanya program ini, ke depan diharapkan siswa akan lebih aktif, produktif, kreatif, berakhlakul karimah, serta dapat memiliki emotional quotient (EQ) yang ideal. Emotional quotient sangat dibutuhkan di era sekarang ini, karena dengan adanya emotional quotient diharapkan siswa memiliki emosi yang benar-benar stabil dan mampu menjadi pribadi yang "matang" (Sumber observasi di lapangan). Siswa yang memiliki emotional quotient yang baik, akan dapat mengendalikan dirinya dengan baik pula dalam konteks pembelajaran di sekolah. Hal inilah yang dapat dijadikan sebagai modal utama bagi siswa untuk meraih hasil belajar yang maksimal, baik dalam konteks akademik maupun non akademik. Melihat begitu pentingnya program pengajaran kokurikuler dan kemampuan emotional quotient bagi siswa. Maka penelitian ini dirumuskan dengan judul "Progam Pengajaran Kokurikuler dalam Meningkatan Kemampuan Emotional Quotient Siswa MTs Tahfidz Yanbu'ul Qur'an Kudus".

\section{B. METODE PENELITIAN}

Jenis penelitian yang digunakan adalah field research atau penelitian lapangan, dengan pendekatan kualitatif. Penelitian ini dilakukan di MTs Tahfidz Yanbu'ul Qur'an Kudus. Sumber data primer penelitian ini adalah kepala madrasah, waka kurikulum, guru, dan siswa. Sedangkan data sekunder penelitian ini adalah buku, jurnal ilmiah, serta penelitian-penelitian terdahulu yang relevan. Teknik pengumpulan data menggunakan 
observasi, wawancara serta dokumentasi. Pengolahan data menggunakan triangulasi baik teknik, waktu, maupun sumber.

\section{HASIL DAN PEMBAHASAN}

Berdasarkan proses observasi dan pengumpulan data di lapangan, diperoleh data bahwa:

\section{Pelaksanaan Program Pengajaran Kokurikuler dalam Meningkatkan Emotional Quotient (EQ) Siswa MTs Tahfidz Yanbu'ul Qur'an Kudus}

Program pengajaran kokurikuler merupakan sebuah kegiatan pendidikan yang dilakukan di luar kegiatan pembelajaran formal. Meskipun di luar kegiatan pembelajaran, guru dapat mengintegrasikannya dalam sebuah pembelajaran. Tujuan utamanya adalah agar siswa lebih mendalami dan menghayati apa yang sudah dipelajari dalam kegiatan intrakurikuler. Kegiatan kokurikuler dapat dilaksanakan di mana saja, mulai dari perpustakaan, rumah, atau tempat lainnya yang mendukung kegiatan tersebut. Tujuan lain dari program ini adalah untuk membangun harga diri dan mengembangkan potensi siswa dengan catatan diarahkan kepada peningkatan keimanan dan ketaqwaan kepada Allah SWT (Sri Narwanti, 2016: 55).

Program pengajaran kokurikuler di MTs Tahfidz Yanbu'ul Qur'an Kudus merupakan sebuah program unggulan selain tahfidz. Program ini dapat berjalan dengan baik karena masing-masing komponen saling mendukung dan bersinergi guna mensukseskan program kokurikuler ini. Tanpa adanya kemauan dan sistem yang benar-benar tersusun rapi akan sangat sulit untuk menjalankan program ini. Dikarenakan padatnya aktivitas siswa, mulai dari bangun tidur hingga tidur lagi. Selain itu, fokus utama kegiatan siswa adalah menghafal Al-Qur'an, namun tidak mengesampingkan ilmu umum. Ada unsur balancing di dalam proses pembelajarannya. Di dalam konteks pelaksanaannya, program kokurikuler tidak menggunakan kurikulum khusus. Melainkan berpedoman pada kurikulum sekolah pagi. Kurikulum merupakan sebuah acuan pokok yang digunakan untuk melaksanakan kegiatan belajar mengajar. Dengan adanya kurikulum diharapkan 
kegiatan pengajaran dapat berjalan sesuai dengan alur dan memiliki tujuan yang jelas (Hendro Ari, 2012: 103).

Berdasarkan penjelasan dari Kepala MTs Tahfidz Yanbu'ul Qur'an Kudus, selama program kokurikuler ini berjalan tidak ada kendala yang signifikan. Itu artinya pelaksanaan program ini berjalan dengan baik dan kondusif. Program ini juga dapat meningkatkan kemampuan siswa dalam banyak hal, utamanya kemampuan emotional quotient. Menurut pandangan beliau, EQ wajib dimiliki oleh setiap siswa. Karena apabila memiliki EQ yang positif maka dengan otomatis siswa tersebut akan memiliki akhlak yang positif pula (terpuji). Karena sebagian besar yang dikerjakan oleh setiap individu berasal dari hati dan perasaan. Oleh karena itu, program kokurikuler ini dapat digunakan untuk meningkatkan kemampuan EQ pada siswa. Contoh nyata adalah siswa yang rajin mengikuti program kokurikuler sebagian memiliki kepribadian yang lebih baik. Siswa tersebut memiliki jiwa menghargai, tanggung jawab, empati, serta memiliki motivasi yang tinggi dalam hal akademik maupun non akademik. Berbeda dengan siswa yang malas mengikuti program kokurikuler, siswa tersebut cenderung acuh terhadap sesama dan prestasi akademiknya juga rendah (Sumber Wawancara dengan Kepala Madrasah). Menurut Wakil Kepala Bidang Kurikulum MTs Tahfidz Yanbu'ul Qur'an Kudus, program kokurikuler ini sudah ada sejak pondok dan madrasah ini didirikan. Istilah lain dari program ini adalah belajar malam atau kelas malam. Dimulai dari pukul 20.30 hingga 21.30 WIB. Materi yang diajarkan adalah empat mata pelajaran umum yaitu Bahasa Indonesia, Matematika, Bahasa Inggris, dan Ilmu Pengetahuan Alam. Ditambah materi muhadatsah bahasa Arab dan metode tamyis. Tujuan awal dari program ini adalah untuk mensukseskan kegiatan UNBK yang akan mereka ikuti di kelas sembilan (9). Persiapan sejak dini memang sengaja dilakukan, karena madrasah ini tidak mengenal adanya pemadatan materi menjelang UNBK. Pelaksanaan program kokurikuler juga dapat meningkatkan EQ siswa. Hal ini terbukti dengan siswa yang sering mengikuti program kokurikuler memiliki tingkat interaksi sosial yang baik, motivasi belajar yang tinggi, dan jiwa empati terhadap sesama yang tinggi pula. Semua unsur tersebut sudah ada dalam masing-masing diri 
siswa. Sehingga indikator seseorang dapat dikatakan memiliki EQ sudah terpenuhi (Sumber Wawancara dengan Waka Kurikulum Madrasah).

Salah satu unsur penting di dalam emotional quotient (EQ) adalah motivasi. Program kokurikuler diharapkan dapat meningkatkan motivasi siswa dalam hal kegiatan belajar mengajar. Motivasi merupakan dorongan yang muncul pada diri seseorang secara sadar maupun tidak untuk melakukan tindakan dengan sebuah tujuan tertentu. Motivasi akan dapat mempengaruhi jiwa seseorang dan pada akhirnya akan membentuk sebuah pribadi yang diinginkan (Hawari, 2012: 78). Kegiatan kokurikuler menggunakan metode yang sangat beragam dalam menyampaikan materi pelajaran kepada siswa. Metode mengajar penting dipilih, karena metode yang tepat dan menarik diharapkan semangat siswa dalam mengikuti pembelajaran tersebut juga meningkat. Serta tujuan pembelajaran dapat dicapai dengan maksimal. Salah satu kegiatan belajar mengajar bisa dikatakan sukses adalah apabila daya serap terhadap materi pelajaran yang diajarkan mencapai prestasi tertinggi, baik dalam konteks individu maupun kolektif (Moh Uzzer: 1993, 8).

Hal senada disampaikan salah seorang siswa kelas VII. Ia mengatakan dalam kegiatan kokurikuler berupa kelas malam, para guru menggunakan metode mengajar yang sangat beragam dan membuat siswa sangat rileks dalam pembelajaran. Ia merasa setelah mengikuti kegiatan ini, dapat menjalani aktivitas sehari-hari dengan lebih tertib dan teratur. Serta memiliki motivasi yang tinggi dalam hal apapun, utamanya guna menyelesaikan hafalan Al-Qur'an 30 Juz (Sumber Wawancara dengan Siswa Madrasah). Program kokurikuler didesain semenarik mungkin dan sefleksibel mungkin. Salah satu yang menarik di dalam pelaksanaannya adalah, para guru diwajibkan memberikan nasehat-nasehat kepada siswa. Tujuannya adalah agar siswa benar-benar memiliki tingkat emosi yang ideal. Tanpa dibekali dengan kecerdasan emosi yang maksimal, akan sulit seorang siswa dapat mewujudkan semua tanggung jawabnya tersebut. Kegiatan kokurikuler berlangsung seperti pada umumnya, yaitu guru mengawali pembelajaran dengan: 
a. Kegiatan awal/pendahuluan, dalam hal ini guru membuka pembelajaran dengan mengucapkan salam dilanjutkan dengan berdo'a bersama. Selanjutnya guru meminta siswa mengamati sekelilingnya untuk mengecek kebersihan (apabila ada sampah, wajib diambil dan dibuang ke tempat sampah). Guru melakukan absensi kepada seluruh siswa. Guru menjelaskan materi apa yang akan dipelajari pada pertemuan itu disambung dengan apersepsi dan tanya jawab ringan untuk memberikan stimulus bagi siswa.

b. Kegiatan inti, dalam kegiatan ini terdapat beberapa aspek yang dikerjakan oleh seorang guru. Mulai dari aktivitas mengamati, menyimak, menanya, mendiskusikan, dan mengapresiasi. Namun di dalam kegiatan ini metode yang sering digunakan para guru di MTs Tahfidz Yanbu'ul Qur'an Kudus adalah ceramah, diskusi, dan kerja kelompok.

c. Kegiatan akhir, di dalam kegiatan ini biasanya guru mengadakan tanya jawab untuk review terhadap apa yang sudah dipelajari sebelumnya. Ini penting karena untuk mengetahui apakah siswa masih "ON" atau sudah "OFF". Kemudian dilanjutkan menutup pembelajaran dengan berdo'a bersama.

Melihat berbagai macam penjelasan di atas maka peneliti dapat katakan bahwa, dalam pelaksanaan program pengajaran kokurikuler dalam meningkatkan EQ siswa berjalan dengan baik dan kondusif. Program kokurikuler benar-benar mampu meningkatkan EQ pada diri masing-masing siswa. Dengan catatan program ini selalu dijalankan dengan penuh sinergi dari semua pihak, terutama antara guru dan siswa. Dua komponen ini merupakan pelaku utama dari program ini. Selain itu, dalam penyampaian materi juga diperlukan berbagai macam inovasi metode. Ini yang sudah dilakukan oleh para guru di MTs Tahfidz Yanbu'ul Qur'an Kudus. Karena dengan metode yang tepat, tujuan pembelajaran juga akan mudah untuk dicapai.

2. Faktor Pendukung dan Penghambat Program Pengajaran Kokurikuler dalam Meningkatkan Emotional Quotient (EQ) Siswa MTs Tahfidz Yanbu'ul Qur'an Kudus 
Suatu program yang dijalankan pasti di dalamnya terdapat faktor pendukung dan faktor penghambat, tidak terkecuali pada pelaksanaan program pengajaran kokurikuler dalam meningkatkan emotional quotient (EQ) siswa MTs Tahfidz Yanbu'ul Qur'an Kudus. Berhasil tidaknya program tersebut karena dipengaruhi beberapa faktor. Adapun faktor pendukung dari pelaksanaan program kokurikuler dalam meningkatkan EQ adalah sebagai berikut:

a. Kompetensi guru yang berkualitas

Guru adalah komponen penting dalam dunia pendidikan. Di pundak guru siswa menggantungkan harapannya melalui sebuah pembelajaran. Benci tidaknya siswa terhadap pelajaran bergantung pada bagaimana guru mengajar. Guru merupakan ujung tombak sistem pendidikan, sebagai ujung tombak seorang guru harus benar-benar mempunyai kualitas dan kemampuan yang bisa dipertanggung jawabkan (Hendro: 2012, 101-103). Ketika guru sudah mempunyai kompetensi yang berkualitas, maka dapat dikatakan bahwa $80 \%$ tujuan pendidikan yang diharapkan akan bisa dicapai dengan mudah. Pada dasarnya kompetensi guru dibagi menjadi empat macam, yaitu kompetensi pedagogik, kompetensi kepribadian, kompetensi sosial dan kompetensi profesional. Dimana keempat kompetensi ini wajib dimiliki oleh setiap guru. Kompetensi pedagogik merupakan sebuah kemampuan yang harus dimiliki oleh seorang guru meliputi pemahaman terhadap siswa, perencanaan dan pelaksanaan pembelajaran, evaluasi hasil belajar, hingga pengembangan siswa terkait potensi yang dimiliki. Sub kompetensi yang terdapat di dalam kompetensi pedagogik ini adalah memahami karakteristik siswa dari berbagai aspek (fisik, sosial, moral, kultur, emosional, dan intelektual), memahami latar belakang keluarga dan masyarakat siswa, menguasai teori dan prinsip belajar serta pembelajaran yang mendidik, mampu merancang pembelajaran, mampu melaksanakan pembelajaran, dan mampu mengevaluasi proses dan hasil pembelajaran. Kompetensi kepribadian, kompetensi ini merupakan sebuah kompetensi yang berhubungan dengan kemampuan personal yang wajib dimiliki guru meliputi kepribadian yang mantap, stabil, dewasa, arif, dan berwibawa guna dijadikan teladan bagi siswa. 
Sub kompetensi yang terdapat di dalam kompetensi kepribadian meliputi menampilkan diri sebagai pribadi yang mantap, arif, dan berwibawa, menampilkan diri sebagai pribadi yang memiliki akhlak mulia, mampu introspeksi diri sendiri, dan mampu mengembangkan diri (Muhammad Nurtanto: 2016, 556-557).

Kompetensi sosial merupakan sebuah kompetensi yang berhubungan dengan kemampuan seorang guru untuk dapat berkomunikasi dan berinteraksi secara efektif dan efisien dengan sesama guru, siswa, wali murid, serta masyarakat luas (Fathorrahman: 2017, 2). Ada empat indikator yang menunjukkan keberhasilan guru dalam bidang sosial yaitu sebagai berikut: bersikap inklusif, objektif, serta tidak diskriminatif. Selain itu juga harus mampu berkomunikasi dengan efektif dan berkomunikasi dengan komunitas profesi sendiri dan profesi lain secara lisan dan tulisan.

Kompetensi keempat adalah kompetensi profesional. Kata profesional diartikan sebagai sangat mampu dalam melakukan sebuah pekerjaan. Sehingga kompetensi profesional merupakan kemampuan yang dimiliki seorang guru dalam melaksanakan kewajiban-kewajibannya dengan penuh tanggung jawab, atau dengan kata lain guru tersebut benar-benar pandai dalam menjalankan profesinya, yaitu profesi keguruannya (Muhibbin: 2014, 229). Sub kompetensi profesional meliputi menguasai keilmuan yang diajarkannya, menguasai kurikulum terkait materi yang diajarkannya, mampu menguasai dan memanfaatkan teknologi dalam kegiatan pembelajaran, serta mampu meningkatkan kualitas pembelajaran (Muhammad Nurtanto: 2016, 559). Terdapat 5 indikator guru yang memiliki kompetensi profesional sebagaimana berikut: pertama, menguasai materi, struktur, konsep dan pola pikir keilmuan yang mendukung mata pelajaran yang diampu. Kedua, menguasai standar kompetensi dan kompetensi dasar mata pelajaran yang diampu. Ketiga, mengembangkan materi pembelajaran secara kreatif. Keempat, mengembangkan keprofesionalan secara berkelanjutan dengan melakukan tindakan reflektif. 
Kelima, memanfaatkan teknologi informasi dan komunikasi untuk mengembangkan diri (Wahab: 2011, 15).

Hal ini sejalan dengan kualitas guru yang terdapat di MTs Tahfidz Yanbu'ul Qur'an Kudus. Ini bisa terwujud karena seleksi ketat yang harus ditempuh oleh calon-calon guru yang ingin mengabdi di MTs ini. Tentu hal positif seperti ini patut dijadikan contoh bagi madrasah-madrasah lainnya. Dengan tujuan untuk lebih memajukan pendidikan dan kualitas guru di Indonesia, agar pendidikan Indonesia dapat berbicara banyak dikancah Internasional.

b. Sarana dan prasarana

MTs Tahfidz Yanbu'ul Qur'an Kudus mempunyai sarana dan prasarana yang sangat lengkap. Mulai dari kelas yang letaknya representatif, laboratorium IPA, perpustakaan, dan fasilitas-fasilitas pendukung lainnya. Menurut keterangan Kepala Madrasah bahwa madrasah ini berusaha menciptakan lingkungan yang nyaman dan kondusif untuk melaksanakan sebuah pembelajaran, agar siswa dalam menerima pelajaran juga merasa nyaman. Jika siswa sudah nyaman, maka pelajaran yang diajarkan akan mudah untuk diserap. Seperti halnya di dalam kelas, hampir seluruh kelas sudah memiliki fasilitas pokok yaitu meja, kursi, projektor, papan tulis, kipas angin, hingga loker bagi masing-masing siswa untuk menyimpan buku pelajaran mereka.

c. Monitoring dari Kepala Madrasah

Monitoring merupakan sebuah aktivitas yang sangat penting dilakukan apabila menginginkan sebuah program berjalan dengan lancar dan maksimal. Ini sejalan dengan apa yang dilaksanakan oleh pimpinan MTs Tahfidz Yanbu'ul Qur'an Kudus, yaitu Kepala Madrasah beserta jajarannya. Monitoring terkait program pengajaran kokurikuler dilakukan rata-rata setiap satu bulan dua kali. Monitoring ini meliputi pemantauan dan pengecekan terhadap pelaksanaannya, kendala-kendala yang dialami selama pelaksanaan program ini, dan juga meminta masukan dari para guru agar program ini kedepannya dapat berjalan dengan lebih baik lagi. Dilihat dari kegiatan tersebut, menunjukkan bahwa dari 
pihak pimpinan madrasah memang memberikan perhatian dan dukungan yang luar biasa terhadap suksesnya pelaksanaan program ini. Sebuah program dapat berjalan dengan maksimal jika semua pihak terkait tahu akan tugas dan tanggung jawabnya masing-masing.

Sedangkan faktor yang menghambat pelaksanaan program kokurikuler dalam meningkatkan EQ adalah sebagai berikut:

a. Masih kurangnya tenaga pendidik

Pendidik atau guru merupakan salah satu subjek penentu suksesnya sebuah pendidikan. Jika dari segi gurunya belum maksimal, maka akan sulit untuk mensukseskan sebuah program pengajaran. Hal inilah yang terjadi terhadap program pengajaran kokurikuler. Berdasarkan keterangan dari Waka Kurikulum di MTs Tahfidz Yanbu'ul Qur'an Kudus bahwa MTs ini masih sangat kekurangan tenaga guru, terutama untuk program kokurikuler. Hal ini dikarenakan madrasah ini tergolong sebagai madrasah baru, selain itu juga proses seleksi yang cukup ketat dan lokasi yang sangat jauh dari perkotaan. Alasan inilah yang menyebabkan MTs ini masih kekurangan tenaga guru. Sehingga dari hal tersebut menyebabkan pelaksanaan program pengajaran kokurikuler terkadang berjalan dengan tidak maksimal, akibatnya tentu adalah peningkatan kemampuan emotional quotient (EQ) terhadap siswa akan berjalan kurang maksimal.

b. Waktu pelaksanaan

Program pengajaran kokurikuler dilaksanakan pada malam hari setelah para siswa menyelesaikan kegiatan halaqah dan makan malam. Biasanya program kokurikuler dimulai pukul 20.30 WIB hingga 21.30 WIB. Melihat waktu tersebut, tentu sudah tergolong larut malam bagi anak-anak seusia madrasah tsanawiyah. Di waktu tersebut banyak siswa yang sudah mulai merasa lelah karena seharian sudah beraktivitas penuh, selain itu juga rasa mengantuk yang datang dengan tiba-tiba menghinggapi diri mereka. Inilah yang menyebabkan program pengajaran kokurikuler berjalan dengan tidak maksimal. Apabila jika waktu Isya' molor dari jadwal sebelumnya, sudah pasti kegiatan belajar malam 
juga akan molor dari jadwal yang semula. Namun berdasarkan pengamatan peneliti, meskipun para siswa merasa lelah. Mereka tetap mengikuti kegiatan kokurikuler dengan seksama. Karena program ini merupakan program wajib yang harus mereka ikuti setiap malamnya, kecuali hari libur.

c. Faktor non teknis

Dalam pelaksanaan program pengajaran kokurikuler, terdapat faktor non teknis yang dapat menghambat berjalannya program ini. Hal ini dikuatkan dengan pernyataan dari Kepala di MTs Tahfidz Yanbu'ul Qur'an Kudus. Beliau mengatakan bahwa kendala yang biasanya mengganggu kegiatan kokurikuler adalah cuaca buruk, terutama pada saat musim hujan. Karena pondok/madrasah ini terletak di pegunungan, jika terjadi hujan deras maka situasi tidak akan kondusif. Maka dampaknya adalah pembelajaran tidak dapat berjalan dengan maksimal. Selain itu, ditambah dengan padamnya listrik. Karena untuk menghidupkan generator membutuhkan waktu yang tidak sebentar, dikarenakan daya besar di lingkungan madrasah ini. Ditambah lagi terkadang terdapat guru yang izin mendadak tanpa memberikan tugas kepada siswa. Tentu hal ini akan menyebabkan pembelajaran berjalan dengan seadanya.

Berdasarkan analisa yang peneliti lakukan dengan melihat penjelasan di atas, maka dengan adanya faktor pendukung dan penghambat terhadap pelaksanaan program pengajaran kokurikuler dalam meningkatkan emotional quotient (EQ) siswa MTs Tahfidz Yanbu'ul Qur'an Kudus, dapat digunakan sebagai refleksi bagi pihak madrasah guna melakukan evaluasi terkait program ini. Dengan catatan tetap mempertahankan dan bahkan meningkatkan faktor pendukung yang sudah ada, disamping itu juga harus segera memperbaiki faktor penghambat yang ada. Hal ini tentu penting, agar peningkatan emotional quotient (EQ) dalam diri siswa setiap tahunnya dapat meningkat.

\section{KESIMPULAN}


Berdasarkan hasil penelitian dengan judul "Program Pengajaran Kokurikuler dalam Meningkatkan Kemampuan Emotional Quotient (EQ) Siswa MTs Tahfidz Yanbu'ul Qur'an Kudus", maka kesimpulannya adalah sebagai berikut:

1. Pelaksanaan program pengajaran kokurikuler dalam meningkatkan kemampuan EQ siswa di MTs Tahfidz Yanbu'ul Qur'an Kudus secara umum sudah berjalan dengan baik dan maksimal. Kegiatan kokurikuler bertujuan untuk memberikan pemahaman dan pendalaman terhadap materi yang diajarkan saat sekolah formal pagi. Selain itu untuk menyiapkan siswa dalam menghadapi UNBK. Berkaitan dalam hal peningkatan EQ siswa, dapat disimpulkan bahwa dengan program pengajaran kokurikuler dapat meningkatkan EQ pada diri siswa. Hal ini dibuktikan dengan siswa yang sering mengikuti program kokurikuler memiliki kepribadian yang lebih baik, memiliki rasa menghargai yang tinggi, bertanggung jawab, empati, serta bermotivasi tinggi. Sedangkan siswa yang malas mengikuti program ini cenderung bersifat acuh tak acuh terhadap sesama, dan prestasi akademik maupun non akademiknya rendah.

2. Faktor pendukung pelaksanaan "Program Pengajaran Kokurikuler dalam Meningkatkan Kemampuan Emotional Quotient (EQ) Siswa MTs Tahfidz Yanbu'ul Qur'an Kudus yaitu kompetensi guru yang berkualitas, sarana dan prasarana, serta monitoring dari kepala madrasah. Sedangkan faktor yang menghambat yaitu masih kurangnya tenaga pendidik, waktu pelaksanaan, dan faktor non teknis.

\section{DAFTAR PUSTAKA}

Aka Hawari. (2012). Guru Yang Berkarakter Kuat. Jakarta: Laksana.

Fathorrahman. (2017). Kompetensi Pedagogik, Profesional, Kepribadian dan Kompetensi Sosial Dosen. Akademika: Vol. 15 No. 1, Edisi 1 Januari 2017. http://jurnal.stieimalang.ac.id/index.php/JAK/article/download/67/33

Islamuddin Haryu. (2014). Psikologi Pendidikan. Jember: STAIN Jember Press.

Jihad Asep., \& Abdul Haris. (2013). Evaluasi Pembelajaran. Yogyakarta: Multi Pressindo. 
Mudyaharjo Redja. (2013). Pengantar Pendidikan: Sebuah Studi Awal Tentang DasarDasar Pendidikan Pada Umumnya dan Pendidikan Di Indonesia. Depok: PT Raja Grafindo Persada.

Narwanti Sri. (2016). Pendidikan Karakter: Pengintegrasian 18 Nilai Pembentuk Karakter Dalam Mata Pelajaran. Yogyakarta: Familia.

Nurtanto Muhammad. (2016). Mengembangkan Kompetensi Profesionalisme Guru Dalam Menyiapkan Pembelajaran Yang Bermutu. http://www.jurnal.fkip.uns.ac.id/index.php/snip/article/view/8975

Setyono, Hendro Ari dkk. (2012). Pengantar Pendidikan. Jakarta: PT Prestasi Pustakaraya.

Syah Muhibbin. (2014). Psikologi Pendidikan Dengan Pendekatan Baru. Bandung: PT Remaja Rosdakarya.

Usman, Moh Uzzer., \& Lilis Setiawati. (1993). Upaya Optimalisasi Kegiatan Belajar Mengajar. Bandung: Remaja Rosdakarya.

Wahab dkk. (2011). Kompetensi Guru Agama Tersertifikasi. Semarang: Robar Bersama. 